\title{
THE INFLUENCE OF AGE ON THE HÆMOGLOBIN LEVEL IN CONGENITAL HEART DISEASE
}

\author{
BY \\ R. J. SHEPHARD \\ From The Cardiac Department, Guy's Hospital \\ Received March 25, 1955
}

The hæmoglobin content of the blood is a convenient out-patient test, and it has some value in the assessment of cyanotic heart cases both before and after operation (Campbell and Deuchar, 1953 and Campbell, Deuchar, and Brock, 1954). However, the theoretical background to variations of the hæmoglobin level in congenital heart disease is not well understood.

When the oxygen tension of arterial blood is reduced by altitude, it is comparatively easy to demonstrate an inverse relationship between oxygen tension and hæmoglobin level (Fitzgerald, 1913; Hurtado et al., 1945), but in congenital heart disease the relationship is less obvious. This has variously been attributed to the presence of a severe associated disease (Talbot et al., 1941), to a relative deficiency of iron (Brinton, 1951), and to the complicating effect of possible changes in circulatory flow (Holling, 1952). Little attention has so far been focused on the effect of age of the patient, although it is clear that most high altitude studies have been conducted on homogeneous populations of adults, while the congenital heart series have always included a large and rather varied proportion of children. It was therefore thought of interest to examine data from a large group of congenital heart patients, acyanotic as well as cyanotic, in order to determine the influence of age.

\section{Methods}

Collection of Blood Samples. The sampling errors introduced by prolonged venous or capillary stasis have been discussed by Peterson et al. (1943). For the present purpose, blood samples were collected directly from the right side of the heart and from the femoral artery during the course of cardiac catheterization. Samples were kept in syringes at $0^{\circ} \mathrm{C}$. for a maximum of 2-3 hours. The syringes were lubricated with silicone and contained a trace of heparin and one drop of mercury. Prior to analysis the syringes were shaken for 1-2 minutes to allow mixing and warming to room temperature, and then the contents were transferred anaerobically to Ostwald pipettes. Five or six independent samples were obtained from each subject.

Method of Analysis. The percentage saturation and total oxygen capacity of the samples were estimated by the Haldane blood gas analysis apparatus (Douglas and Priestley, 1948). The repeatability of measurements by this technique is quite good, the oxygen uptake in any one estimate usually differing by no more than $0.001 \mathrm{ml}$. from the mean value, and the oxygen capacity rarely differing by more than $0.005 \mathrm{ml}$. from the mean value (Ernsting and Shephard, 1951). The original technique, using bicarbonate buffers, gave values for oxygen capacity that were 5-7 per cent lower than those obtained by the Van Slyke apparatus (Bierring et al., 1937), this error arising largely from oxidation of the lipoid fraction of the plasma (Litarczek, 1928). However, it has now been shown that if borate buffer of $p \mathrm{H} 10$ be used in place of the bicarbonate buffer, there is no systematic difference between the Haldane and Van Slyke methods (Courtice and Douglas, 1947).

The Subjects. The patients taking part in this investigation were 350 unselected cases of congenital heart disease-166 acyanotic, and 184 cyanotic. Their ages ranged from 2-60. Patients under the age of 6 were invariably under light pentothal anæsthesia, and some patients in the 7- and 8-year age groups were also given a general anæsthetic. Pentothal was originally selected as the anæsthetic agent because it was 
believed that this would not affect the blood gas estimations; there has been one report suggesting that in dogs, pentothal produces some hæmodilution (Penrod and Hegnauer, 1948), but in the present series there was no difference between anæsthetized and conscious children of a comparable age group.

ANALYsis of Results

Patients were divided into two broad groups, the cyanotic and the acyanotic, on the basis of arterial oxygen saturation. The dividing line (breathing air) was taken as 94 per cent in the conscious and 92 per cent in the anæsthetized patients.

Having divided the patients in this way, the acyanotic patients should give some indication of the influence of cardiac disease on hæmoglobin production, uncomplicated by the effects of changes in arterial oxygen tension. To facilitate this analysis, cases were grouped according to age, as shown in Table I. Up to the age of 15, there was little difference between the sexes, and they have not therefore been distinguished. Over the age of 15 , the women patients showed a slightly lower hæmoglobin level than the men, the difference being statistically significant in the $19 \cdot 5-29 \cdot 5$-years age group.

TABLE I

Hemoglobin Level at Different Ages

(Mean and standard error)

\begin{tabular}{|c|c|c|c|}
\hline Age & \multicolumn{2}{|c|}{ Acyanotic patients } & Cyanotic patients \\
\hline $\begin{array}{c}2 \cdot 5-4 \cdot 5 \\
4 \cdot 5-5 \cdot 5 \\
5 \cdot 5-6 \cdot 5 \\
6 \cdot 5-7 \cdot 5 \\
7 \cdot 5-8 \cdot 5 \\
8 \cdot 5-9 \cdot 5 \\
9 \cdot 5-10 \cdot 5 \\
10 \cdot 5-11 \cdot 5 \\
11 \cdot 5-12 \cdot 5 \\
12 \cdot 5-13 \cdot 5 \\
13 \cdot 5-14 \cdot 5 \\
14 \cdot 5-15 \cdot 5\end{array}$ & \multicolumn{2}{|c|}{$\begin{array}{l}12.9 \pm 0.4 \mathrm{ml} . \mathrm{O}_{2} / 100 \mathrm{ml} \\
13.9 \pm 0.4 \\
14 \cdot 5 \pm 0.8 \\
15 \cdot 0 \pm 0.6 \\
15 \cdot 1 \pm 0.7 \\
15 \cdot 5 \pm 0.6 \\
15.9 \pm 0.9 \\
16 \cdot 1 \pm 0.6 \\
16 \cdot 0 \pm 0.4 \\
16 \cdot 8 \pm 0.4 \\
17 \cdot 2 \pm 0.5 \\
18.6 \pm 0.5\end{array}$} & $\begin{array}{l}21 \cdot 7 \pm 2 \cdot 4 \mathrm{ml} . \mathrm{O}_{2} / 100 \mathrm{ml} \text {. } \\
21 \cdot 0 \pm 2 \cdot 0 \\
22 \cdot 7 \pm 1 \cdot 3 \\
21 \cdot 4 \pm 1 \cdot 6 \\
23 \cdot 1 \pm 1 \cdot 3 \\
23 \cdot 7 \pm 1 \cdot 2 \\
25 \cdot 4 \pm 2 \cdot 8 \\
25 \cdot 2 \pm 1 \cdot 9 \\
24 \cdot 3 \pm 1 \cdot 4 \\
25 \cdot 2 \pm 2 \cdot 0 \\
25 \cdot 8 \pm 1 \cdot 6 \\
23 \cdot 3 \pm 2 \cdot 4\end{array}$ \\
\hline $\begin{array}{l}15 \cdot 5-19 \cdot 5 \\
19.5-29.5 \\
29.5-39.5 \\
39.5-49.5 \\
\text { over } 49.5\end{array}$ & $\begin{array}{c}\text { Men } \\
17 \cdot 4 \pm 0.5 \\
17 \cdot 9 \pm 0.5 \\
17 \cdot 7 \pm 0.3 \\
17 \cdot 2\end{array}$ & $\begin{array}{r}\text { Women } \\
16 \cdot 6 \pm 0 \cdot 7 \\
16 \cdot 1 \pm 0 \cdot 6 \\
17 \cdot 3 \pm 0 \cdot 5 \\
17 \cdot 3 \pm 1 \cdot 0\end{array}$ & $\begin{array}{l}25 \cdot 6 \pm 1 \cdot 1 \\
24 \cdot 0 \pm 0 \cdot 9 \\
21 \cdot 5 \pm 0 \cdot 8 \\
17 \cdot 3 \pm 1 \cdot 5 \\
17 \cdot 5\end{array}$ \\
\hline
\end{tabular}

Does the hæmoglobin/age curve for the acyanotic group of patients differ significantly from normal? Owing to the specialized nature of the cardiac clinic, the patients did not conform to the classical "hospital" sample, but were drawn from a wide area of the country and included all social grades. The figures are therefore best compared with values from the M.R.C. survey (1945), which covered a similar wide cross-section of society. It will be noted (Fig. 1) that the curve for the present group of subjects is set at a lower level than the M.R.C. curve. A further significant feature is the steeper slope shown by the congenital heart cases. There are various possible explanations for these differences but they may well represent a genuine effect of cardiac disease. Many acyanotic patients, particularly the young children, are below average weight, and it seems quite probable that this poor general nutrition is reflected also by a rather low hæmoglobin content of the blood.

Having established a normal hæmoglobin curve for acyanotic congenital heart cases, it is possible to consider how this curve is modified at different ages by the added factor of a reduced arterial oxygen tension. It can be seen (Fig. 2) that the mean curve for the cyanotic patients lies at a much higher level. Like the acyanotic curve it climbs progressively throughout childhood. 


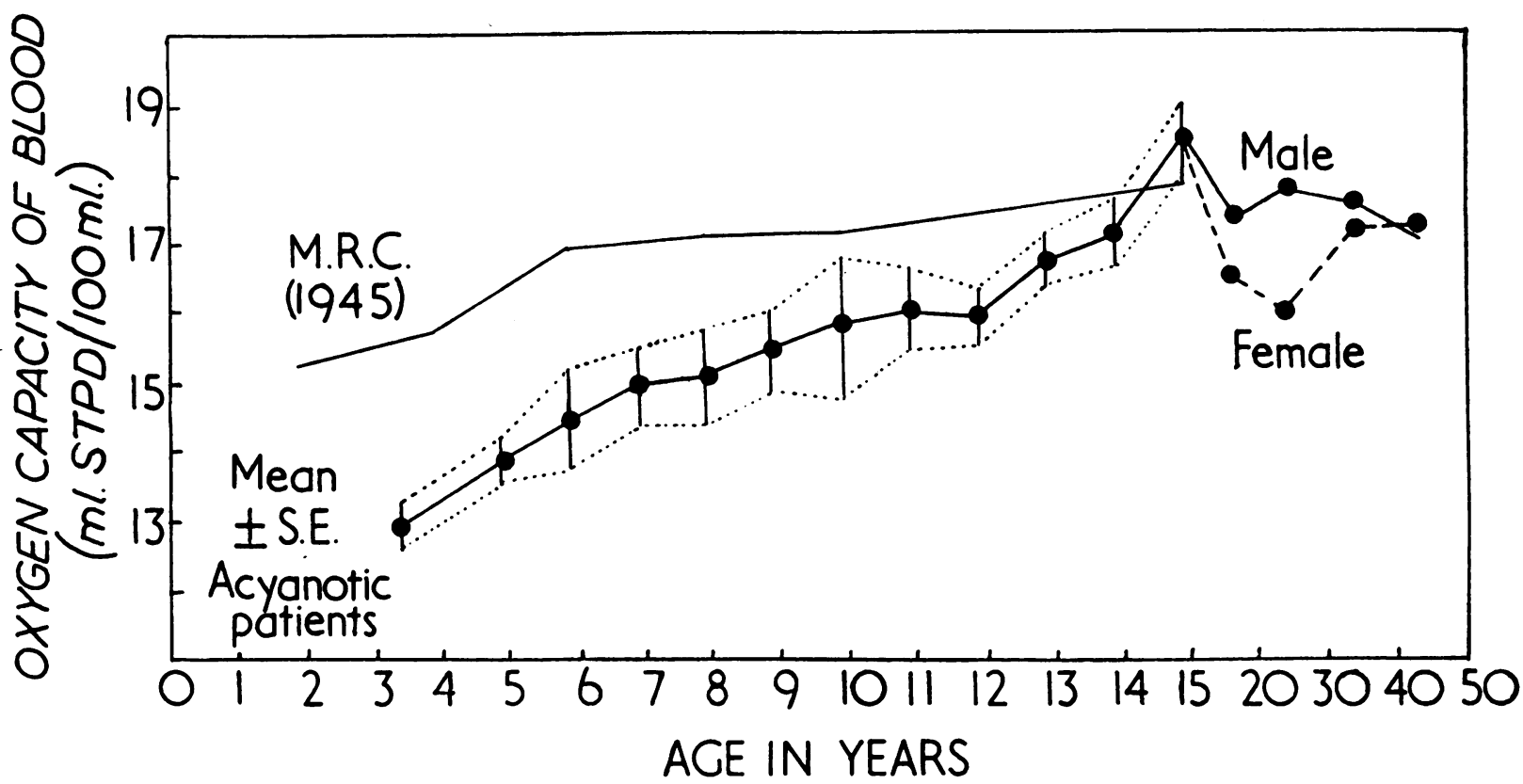

FIG. 1.-The relationship between age and hæmoglobin level (166 cases of acyanotic congenital heart disease). The mean curve (with standard error) is compared with a curve for normal children (M.R.C., 1945).

However, beyond the age of 20 , the curve falls away rapidly, and in the $40-50$ age group there is little difference between acyanotic and cyanotic hæmoglobin levels. This anomaly may be explained by the death of an increasing proportion of the severe cases. Thus only the less severely affected patients with a relatively normal hæmoglobin contribute to the curve during later adult life.

The possibility of distinguishing acyanotic from cyanotic patients on the hæmoglobin level alone is also examined in Fig. 2. To the mean curve for acyanotic cases has been added an area corresponding to twice the standard deviation of a single observation at a given age. This gives an upper limit of normality that will only be transgressed by one patient in twenty, and it is reasonable to suspect patients with a hæmoglobin level greater than this as having a right-to-left shunt. It is important to note that in children under the age of 5, the upper limit of normal oxygen capacity is as low as $15 \mathrm{ml} . / 100 \mathrm{ml}$. (under $75 \%$ hæmoglobin). How many cases with slight cyanosis have a hæmoglobin below the upper limit of normality? It is not possible to answer this question from the standard deviation of the cyanotic curve, since the hæmoglobin level of cyanotic patients shows a skewed distribution, a limiting hæmoglobin level being reached with increasing severity of the heart disease (Brinton, 1951). However, it is possible to indicate on Fig. 2 those of the 184 cyanotic cases that have a hæmoglobin level within normal limits. The percentage at different ages is summarized in Table 2. It would seem that during childhood some 85 per cent of "cyanotic" patients can be recognized purely on hæmoglobin level, but in adult life there is an increasing tendency for the hæmoglobin to fall within normal limits.

\section{DisCUSSION}

It seems clear from the present results that in children the proportion of cyanotic heart cases having an increased hæmoglobin level is sufficient to make this a useful clinical test of a right-to-left shunt. However, if the hæmoglobin level is to be used in this way, it is essential to note both the normal age variation and the general effects of cardiac disease on the hæmoglobin level.

It is well recognized that some degree of iron deficiency anæmia exists in a significant proportion 


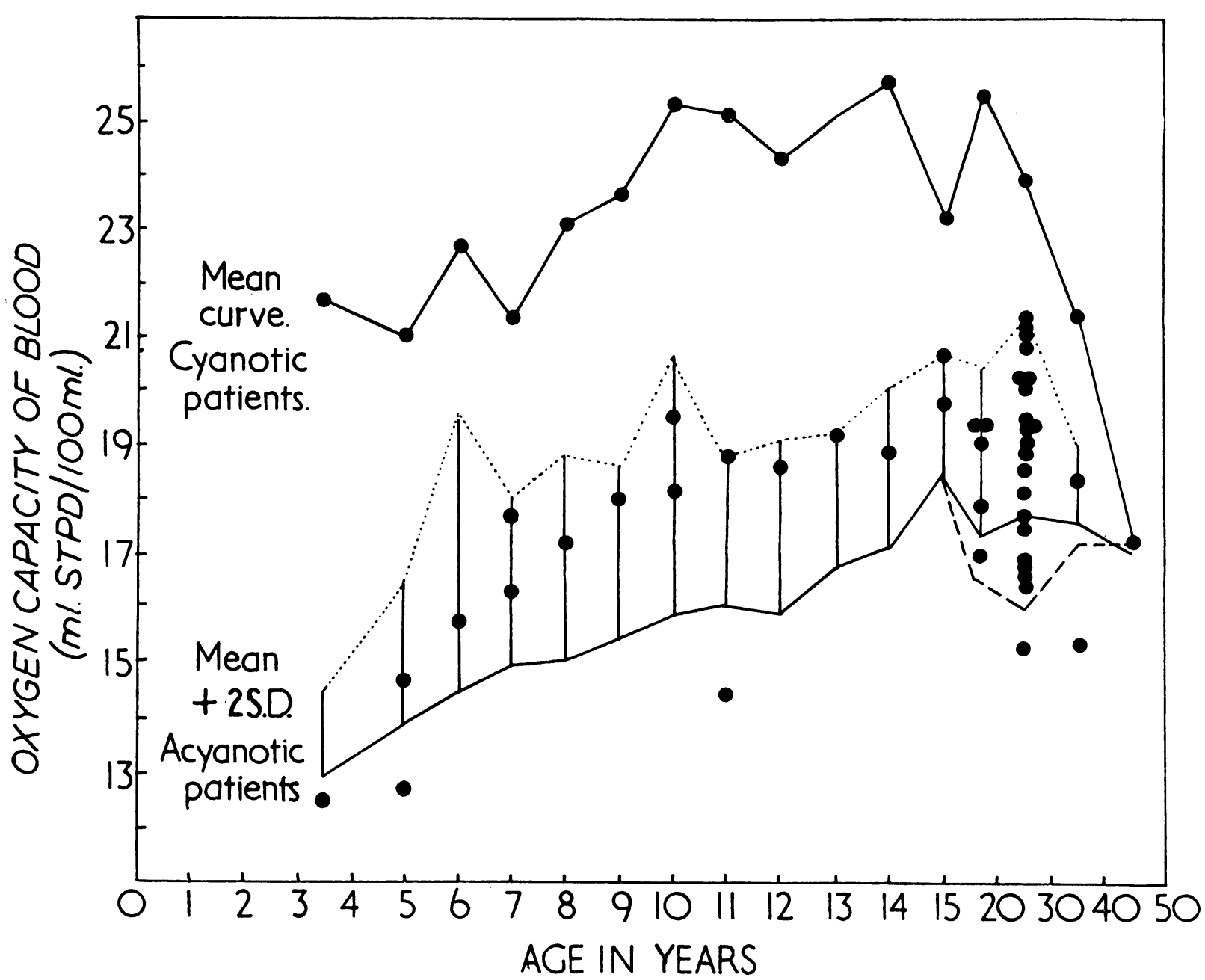

FIG. 2.-The effect of a reduced arterial oxygen tension on the hæmoglobin level in congenital heart disease. The normal limit (twice standard deviation) for acyanotic patients is compared with the mean curve for cyanotic patients. Individual cases of cyanotic heart disease having a hæmoglobin level falling within normal limits are marked on the graph (total number of cyanotic patients 184).

TABLE II

Percentage of Cyanotic Patients with Hamoglobin Level within Normal limits at Diffferfent Ages

\begin{tabular}{c|c|c}
\hline Age group & $\begin{array}{c}\text { Number } \\
\text { of cases }\end{array}$ & $\begin{array}{c}\text { Percentage with } \\
\text { normal hæmoglobin }\end{array}$ \\
\hline $2 \cdot 5-6 \cdot 5$ & 24 & $16 \cdot 7$ \\
$6 \cdot 5-9 \cdot 5$ & 23 & $16 \cdot 9$ \\
$9 \cdot 5-12 \cdot 5$ & 23 & $21 \cdot 7$ \\
$12 \cdot 5-15 \cdot 5$ & 19 & $21 \cdot 1$ \\
$15 \cdot 5-19 \cdot 5$ & 25 & $20 \cdot 0$ \\
$19 \cdot 5-39 \cdot 5$ & 58 & $39 \cdot 6$ \\
\hline
\end{tabular}


of otherwise healthy children (Mackay et al., 1946), but it is not altogether clear whether the incidence of this type of anæmia is increased in the presence of congenital heart disease. However, it is known that many congenital heart cases, acyanotic as well as cyanotic, have a weight that is below average, particularly over the period when parental restriction limits their activity. The present curve for the acyanotic cases lends support to the view that hæmoglobin formation is also inadequate, especially in young children, and such cases might well benefit from iron therapy.

If iron intake falls below requirements in acyanotic cases, the deficiency in the cyanotic is considerably greater, since in this group poor general nutrition is more common, and the iron requirement is much increased by the polycythæmia. Nelson et al. (1947) have pointed out that an improvement in hæmoglobin level can sometimes be brought about by bed rest alone, and it would seem that some other factor-perhaps oxygen lack-is also restricting hæmoglobin formation in the more severe forms of cyanotic heart disease. However, it has been demonstrated (Brinton, 1951) that where the increase of hæmoglobin formation has not kept pace with the polycythæmia, improvement can be achieved by systematic iron therapy without further restriction of a patient's activity, and in cases of this type it would appear beneficial to persist with iron therapy until no further increase of hæmoglobin level can be detected.

The normal red cell count does not vary greatly with age (Moncrieff and Evans, 1953), and is little influenced by the various factors that appear to restrict hæmoglobin formation in congenital heart disease. The relationship between arterial oxygen tension and red cell count therefore remains fairly straightforward, and it is easy to understand why earlier authors found these two variables yielded a better correlation than arterial oxygen tension and hæmoglobin level in cases of congenital heart disease.

\section{SUMMARY}

The relationship between age and hæmoglobin level has been studied in 350 cases of congenital heart disease. The acyanotic cases showed a hæmoglobin level rather lower than previously reported normal values, particularly in the early years of childhood. The mean curve for the cyanotic cases was far above the acyanotic curve throughout childhood, and up to the age of 20 some 85 per cent of cyanotic patients could be distinguished from the acyanotic by estimation of the hæmoglobin level alone. In adult life the hæmoglobin curve for the cyanotic patients gradually merged into the acyanotic curve, perhaps owing to the death of the more severe cyanotic cases.

The rather poor correlation between arterial oxygen tension and hæmoglobin level in cyanotic heart disease is probably due partly to variations of hæmoglobin level with age, and partly to factors restricting hæmoglobin formation in the more severe cases.

The patients forming the basis of this study were under the clinical care of Dr. Campbell, and I am grateful to him for allowing me free access to his records. Nearly 2000 Haldane blood gas analyses were carried out, and it is a pleasure to acknowledge the help given by other members of the Cardiac Department with this work.

\section{REFERENCES}

Bierring, E., Nielsen, A., and Nielsen, E. (1937). Acta med. scand. Supp., 78, 174.

Brinton, W. D. (1951). Guy's Hosp. Rep., 100, 148, 185, 283.

Campbell, M., and Deuchar, D. C. (1953). Brit. med. J., 1, 349. and Brock, R. C. (1954). Brit. med. J., 2, 111 .

Courtice, F. C., and Douglas, C. G. (1947). J. Physiol., 105, 345.

Douglas, C. G., and Priestley, J. G. (1948). Human Physiology-a Practical Course. 3rd. ed., p. 148. Oxford, Clarendon Press.

Ernsting, J., and Shephard, R. J. (1951). J. Physiol., 112, 332.

Fitzgerald, M. P. (1913). Philos. Trans., B., 203, 351.

Holling, H. E. (1952). Clin. Sci., 11, 283.

Hurtado, A., Merino, C., and Delgado, E. (1945). Arch. intern. Med., 75, 284.

Litarczek, G. (1928). J. Physiol., 65, 1. 
Mackay, H. M. M., Dobbs, R. H., Bingham, K., and Martin, W. J. (1946). Arch. Dis. Childh., $21,145$.

Moncrieff, A., and Evans, P. (1953). Garrod Batten \& Thursfield's Diseases of Children. 5th ed., vol. II, p. 10451048. Arnold, London.

Medical Research Council, Special Report Sєries, No. 252. (1945).

Nelson, W., Mayerson, H. S., Clark, J. H., and Lyons, C. (1947). J. clin. Invest. $26,860$.

Penrod, K. E., and Hegnauer, H. A. (1948). Amer. J. Physiol., 153, 81.

Peterson, J. M., Strangeways, D. H., and Jordan, R. C. (1943). J. Physiol., 102, 5 P.

Talbot, J. H., Coombs, F. S., Castleman, B., Chamberlain, F. L., Consolazio, W. V., and White, P. D. (1941). Amer. Heart J., 22, 754. 